\title{
Integrated landscape management of the Ipel river basin
}

\author{
Zita IZAKOVIČOVÁ ${ }^{1 *}$ and Július OSZLÁNYI ${ }^{1}$ \\ ${ }^{1}$ Institute of Landscape Ecology, Slovak Academy of Sciences, Štefániková 3, P. O. BOX. 254, 81499 \\ Bratislava
}

* Correspondence to: Zita Izakovičová, Slovak Academy of Sciences, Slovakia. E-mail: Zita.Izakovicova@savba.sk

\section{(9) GEOREVIEW}

\section{Article history}

Received: August 2012

Received in revised form:

November 2012

Accepted: December 2012

Available online: January

2013

\begin{abstract}
This paper presents an evaluation of the Ipel river basin, examining its sustainable development. It devises methodology for integrated landscape management as a basic tool for the implementation of its sustainable development in actual practice. The main objective of this case study is to define the socio-economic and environmental problems, to design measures to eliminate these problems and/or to prevent new problems arising. The ultimate goal is to achieve management practices which are in harmony with this area's potential, to the greatest possible extent. Thus, basic principles are applied to landscape-ecological optimization of landscape organisation, including nature protection, biodiversity, landscape stability and the protection of its natural resources. These involve its water and soil and the air/atmosphere in its forests. The protection of its cultural-historical resources is extremely important, including, inter alia, the protection of cultural monuments, protection of historical landscape structures and protection of the entire environment.
\end{abstract}

KEY WORDS: sustainable development, landscape management, natural resources, Ipel river basin

\section{Introduction}

Sustainability problems are currently very topical because they are an inevitable precondition for continued human existence. The solution to these accumulated problems is of the utmost importance because they involve depletion and degradation of natural resources, increased threat to biodiversity, impairment of landscape stability, intensified manifestations of natural risks, such as floods, droughts, landslides etc. Therefore, research into sustainability problems originates from pragmatic needs. It is absolutely necessary from the viewpoint of preserving life on Earth. Many professional and political events now deal with sustainability issues. Of these, the Rio Summit ' 92 is most important, because it provided the impetus to solve problems regarding sustainable development at the world-wide level. Although twenty years have elapsed since the Rio Summit, significant progress in the implementation of the principles and criteria for sustainable development have not been implemented. Therefore, global biodiversity continues to be reduced, occurence of natural risks and hazards increases and contamination of the 
environment continues. It is now essential to immediately introduce the concepts of sustainable development into actual practice.

Current definitions and approaches to the concept of "sustainable development" on a worldwide scale are very numerous and heterogeneous. They are based on a variety of aspects, for instance:

"...such a way of the management of natural resources (air, water, soil, mineral resources) and living systems including man, which will ensure the achievement of the highest sustainable quality of life " (IUCN, 1973);

"...development that accepts the limits of the consumption and utilization of natural resources" (Rifkin, 1980);

"...improving the quality of life of man within the carrying capacity of supporting ecosystems" (Caring for the Earth, IUCN, 1991);

"...as life within the bounds of the carrying capacity of biosphere" (Chiras, 1993);

"...process aimed at ensuring an adequate development of all forms of life not excluding human life in a long-term temporal horizon" (Izakovičová, 1995).

The most frequently quoted definition is from Our Common Future, also known as the Brundtland Report (WCED, 1987):

"Sustainable development is development that meets the needs of the present without compromising the ability of future generations to meet their own needs. It contains within it two key concepts:

- the concept of needs, in particular the essential needs of the world's poor, to which overriding priority should be given; and

- the idea of limitations imposed by the state of technology and social organization on the environment's ability to meet present and future needs."

All definitions of sustainable development require that we view the world as one complete system - a system that connects both space and time. As is evident from the above accepted definitions, sustainable development denotes societal development which both regards and respects the natural and cultural-historical resources and environmental protection. In particular, the fundamental goal of sustainability is to harmonize economic development with the protection of nature, natural and cultural-historical resources and also the environment. The basic tool for application of the idea of sustainable development in actual practice is integrated landscape management.

\section{Theoretical and methodical principles}

Integrated landscape management is based on viewing the landscape as the integration of natural resources in a certain area. This area represents an integrated scope; the scene in which all resources occur as intermixed layers, emanating from geological sources, water and soil sources, climatic and biotic sources and also from morphometric parameters. This necessitates viewing the space as an integration of the particular natural resources in a given area. Each point on the earth surface represents a specific homogeneous entity within an integrated combination of these listed resources. Integrated landscape management requires understanding of the 
relationship between these natural resources and landscape building components required to satisfy all human needs and to act as natural resources for human society.

Integrated landscape management has been discussed in different publications (Caims et al., 1994; Sclocombe, 1998; Szaro et al., 1998; Siebert et. al., 2004; Bezák, 2006; Lehotský, 2006; Miklós and Izakovičová, 1997). This management relies on complex landscape research into the three basic areas of environmental, economic and social issues, and research in connections and relationships between these individual areas. The aim is to balance the development of all these facets and not to give precedence to the development of one over the others. Here, economic profit, environmental protection and social benefits must be considered equally.In these circumstances, it is especially sensitive to study relationships between environmental and social areas, because many businesses with negative environmental impact also have great social effects.

According to Izakovičová et al. (1997), the basic principles of integrated landscape management are as follows;

a) Preservation of the overall ecological stability of the landscape as the most general and complex condition for conserving the gene pool, biological diversity, stability and the natural functioning of ecosystems. This will conserve the natural production capacity of the landscape. The preservation of ecological stability is therefore primarily achieved by ecological optimization of the spatial structure of the landscape. This can be achieved through the suitable spatial distribution of landscape elements, and their proper utilization and protection,

b) Protection and rational utilization of natural resource components; in particular, this concerns air, water, soil, and biotic and mineral resources. The state of natural resources is determined by their quantity and the quality of the conditions, Protection and rational utilization of natural resources is achieved partly through the optimal collocation of objects and activities in the area,

c) Protection of the immediate human environment: this involves preserving the quality of air, drinking water and the food chain and reducing negative influences including noise, radiation and waste. Environmental protection against unfavourable influences especially means optimization of technological processes in production branches,

d) Ensuring appropriate standards in the population's quality of life. This will ensure satisfaction of the basic requirements of existence. Primary needs are housing, labour, food and water, and secondary requisites are personal-development, including education, culture, recreation, health treatment and personal, religious and political freedom. These objectives can be achieved by the interaction of economic and legislative measures.

e) Ensuring social and cultural diversity: This is achieved by respecting the national, religious and culture-historical peculiarities of individual communities within the region. This objective - similar to the preceding one - can be ensured by the "ecologization" and humanization of the above structures, and especially by the interaction of economic and legislative procedures and humanization of social consciousness. 


\section{Methodological procedure}

This methodological procedure is based on geo-system comprehension of the landscape (Miklós and Izakovičová, 1997; Mitchley et al., 2005; SENSOR, 2004). It consists of the following basic steps (Table 1):

Table 1. The methodological procedure

Step of the methodological procedure Description

Evaluation of the resources (natural, socio-economic and

I. Analyses

cultural-historical) and potentials of the territory and

evaluation of the present state of their utilization

II. Evaluation

Evaluation the problems appearing from the unsuitable

use of resources and potentials of the area

III. Proposal

Proposal to eliminate the identified current problems nd prevent new ones in the given area.

\section{Application on the study area - Ipel river basin}

The area is important in terms of natural, cultural and historic resources which represent a potential for varied socio-economic activities. The farming potential is given by the existence of quality water and a favourable climate for farm products, including grapevines. The most productive soil complexes include Molic Fluvisols, calcaric Molic Fluvisol, Haplic Chernozems (WRB) on aeolian and aeolian-fluvial non-carbonate and carbonate sediments (Hraško et. al., 1993). Their occurrence is linked to the southern part of the floodplain and hill-land of the River Ipel basin. In addition to intensive large-block agriculture, valuable historic structures of the agricultural landscape have also survived here.

There are two types of historic agricultural landscape structures in this area (Miklós et al., 2003). The first type is linked to the area of secluded homesteads and hamlets, where the combination of original small-block extensively used meadows, pastures, orchards, gardens, fallows, and to a lesser extent vineyards, represent historic agricultural landscape structures. These mainly occur in the vicinity of individual or grouped shops and residential buildings, or else outside the residential area in combined large-blocks of fields and grassland and forest. The second type includes mosaics of small-scale, mostly narrow, fields oriented along the fall lines of slopes, with peg and wire vineyards, grasslands, orchards, gardens, fallows, balks covered by wood vegetation and old abandoned parcels now overgrown by tree and shrub vegetation. The typical features of the historical landscape in this region of the River Ipel Basin are individual cellars or those built next to press-shops on slopes or partly inserted into the slopes. These are arranged in rows, in groups or scattered throughout the vineyards. The significance of the historic landscape structures is especially evident in terms of historic and cultural value, and also within landscaping, social and ecological functions.

Several valuable biotops also survive along with agricenoses of this area. Ten localities with NATURA 2000 biotopes of international significance exist (Ružičková et al. (eds), 1996). Many of 
these are parts of protected territories, and this Basin boasts two National Nature Reserves, three localities of Natural Phenomena and two Protected Areas. The Important European bird territory Niva rieky Ipel' is also located in the Ipel Basin, with typical biotopes of southern Slovakia: water biotope, agricultural landscape and pastures. This is important for species including the white stork (Ciconia ciconia), lesser grey shrike (Lanius minor), little crake (Porzana parva), spotted crake (Porzana porzana), common kingfisher (Alcedo atthis), European bee-eater (Merops apiaster) and the Eurasian scops owl (Otus scops).

As far as wetland ecosystems in this model territory are concerned, the RAMSAR locality of Poiplie is among the most valuable. It is part of the larger wetland spreading into Hungary, and it is a territory with high concentration of natural assets in the spheres of geomorphology, hydrology, botany and zoology. This locality is a typical example of natural lowland alluvial ecosystems of the Pannonian bio-geographical region,with a uniquely preserved combination of wetland biotopes. It includes the susceptible and threatened plant and animal species, and their associations with good population sizes and high diversity. It is an important biotope for nesting and migrating water fowl, it is ideal for fish spawning and it is a site for amphibians, mammals, insects and other animals' reproduction (Slobodník and Kadlečík (eds.), 2000).

The study area of the River Ipel Basin is among the less forested ones in Slovakia. Scarce woodiness is due to its lowland position and intensive farming. Regarding the landscape geomorphology, the forest is not evenly distributed, so that The Forest Land Pool (FLP) prevails in the north, balanced with the Agricultural Land Pool in the south, but the forest is barely represented in the rest of the territory. Forest compounds grow on morphologically dissected relief unsuitable for other forms of exploitation. Several forest associations exist (Michalko et al., 1986). The original alluvial forest survives in fragments. Its greater part exists outside the FLP, mostly within the bank vegetation. The willow-poplar alluvial forest grows on banks of larger streams. Remnants of the Pannonian and Carpathian oak-hornbeam woods grow on moist stands while the higher situated positions are occupied by the beech woods. The dry broad-leafed forests consist of thermophile mixed sub-Mediterranean oak woods, together with admixture of Quercus cerris. Thermophile mixed sub-Mediterranean forests are represented by a complex of forest and grass-herbaceous thermo- and xerophile associations which developed in the warmest and driest stands. These are linked with extreme relief forms such as mountain crests and ridges and abrupt rocky walls. Oak woods are the most widely spread climatic and zonal formations in the whole of the boundary region of the Ipel Basin due to the existing favourable conditions provided by the Krupinská Plateau and the Cerová Upland. These are linked to loess, with moderate slopes, or steeper southerly exposed slopes. There are also secondary forests such as the poplar monocultures, locust and pine woods. As far as economic aspects are concerned, economically exploited woods prevail in this territory while protected forests and those for special purposes form part of the FLP. Apart from economic functions, the forests in this territory also fulfil functions other than merely productive ones. However, the functional productive type is the most frequent here, followed by the counter-erosion/productive and water management/productive types.

Groundwaters in the territory are not sufficient Here, there are several water sources supplying the population of nearby settlements, but besides adequate drinking water, there exists an absolute shortage of water resources. Apart from the Ipel', there are 20 streams in the Basin which supply surface water, and these are therefore important in terms of water management. Natural mineral springs are also important: the chemical composition and physical properties of the springs in Slatina make its use appropriate for therapeutic and consumer purposes (Krahulec et al., 1977). 
The territory is rich in gravel and sand, and this is extracted as natural ballast. Gravel/sand accumulations occur in the Ipel Basin, while stocks of building stones with dominant basalt are also important. However, extraction of raw material often conflicts with nature and natural resources conservation. Extraction also involves direct and secondary interventions into the environment. Direct interventions include extracted spaces, pit heaps, settling pits and also dewatering, while the secondary ones cause terrain subsidence and water contamination. Occasional higher concentrations of natural components contaminate the groundwater with metals or radioactive substances, further adversely affecting the environment.

From a socio-economic viewpoint, this study area is a typical marginal region of Slovakia, characterized by unfavourable socio-economic conditions. It is one of the least developed regions of Slovakia. The main problem in the model territory is a dearth of work opportunities. This causes the high unemployment of around $30 \%$, which sometimes even exceeds $40 \%$. Because of limited work opportunities in rural areas many people are forced to commute to larger cities.

The age structure is also unfavourable, where a large proportion of the population is of postproductive age. Compared with the 1991 figures, all villages in this study area experienced population decrease, through:

Migration of qualified labour force to other regions, particularly abroad, as a result of the lack of job opportunities and low price returns;

Migration of population in the pre-productive age, resulting from the unfavorable life conditions and poor community services;

Decrease in the natural population growth as a result of prevailing mortality above natality. This higher mortality is due to the predominance of post-productive age inhabitants.

Although agricultural production provided the main source of livelihood, agricultural development has remained unfavourable during the last decade. The main problems are the diminution of subsidies and the abandonment of agricultural land. Negative influences on the agricultural development are also due to additional socio-economic factors. These include the lack of financial resources, unfavourable age structure of the population and the low degree of modernization in the agricultural production. The main barrier to agricultural development is the unfavourable age structure of the farmers and agricultural workers. While the older people are unable to adapt to new conditions, younger people have lost interest in agriculture because it is quite tiring and time-consuming work. There are also limited possibilities for employment in other sectors due to insufficient social capital for the development of business activities. The major barriers to economical development include: the predominance of older inhabitants, the low education qualifications of the population, the absence of young business people, the lack of business opportunities already created by their parents and restricted geographical mobility. Characterization of this territory from a socio-economic viewpoint is as follows

Unfavourable economic conditions of this area involve the following parameters:

- A poor economic base and a deficiency in large enterprises,

- The bad financial situation of existing enterprises,

- The low degree of modernization of production, together with limited investment in agricultural development and in the environment,

- Unsatisfactory development of the private sector,

- The difficult accessibility within the region,

- Continual increase in the rate of unemployment, resulting from the lack of work opportunities, 
- Time and financial constraints adversely affecting work attendance,

- The low level of regional and international co-operation,

- Insufficient physical infrastructure is characterized by the following parameters:

- A deficiency in national and international roads,

- The bad technical maintainence of the roads,

- The restricted number of connections,

- The lack of technical infrastructure, such as absence of sewerage, water-supply or central heating in some municipalities,

Unfavourable social conditions are characterised by the following factors:

- The pre-dominance of population in post-productive age accumulating depopulation trends,

- low natural increase as result of the low natality and high mortality,

- migration of the population,

- Unfavourable living conditions, with insufficient household equipment,

- Worsening living standards,

- Abandonment of the houses and properties, leaving premises in very poor condition,

- Low educational level of the population, giving a high unemployment rate and an unfavorable social situation,

- migration of population in the pre-productive age, and emigration of the qualified labour force to other regions,

- The low educational level of the population, together with low level of ecological awareness, and insufficient knowledge resulting from the absence of community information centres,

- absence of social capital for new business activities, with the lack of younger business people, their parents' business acquaintances and positive role models.

\section{Problems of utilisation of resources and potential of the territory}

Various socio-economic activities are developed on the basis of resources and potential. These include occurrence of minerals in the development of mining and processing activities, soil quality, favourable climatic conditions and the development of agriculture and forest resources in forestry development. The natural resources and potential of this territory have not been used effectively. Such inappropriate use of natural resources led to a series of environmental problems, and the following types have been selected in this study area (Miklós et al., 2003):

A. Problems of endangered spatial stability - these were produced due to the territorial clash of stress factors and ecologically important territories. The following types of problems occur in this category:

pollution of water flows, affecting their function as bio-corridors of ecological networks,

- barrier influence of built-up areas on the elements of ecological networks,

- local effects on spatial stability, by formation of a non-functional agricultural landscape. This involves a preponderance of large-area arable land within the structured agricultural landscape of the southern part of the Ipel' and Lučenec basin,

- endangerment of sensitive ecosystems as a consequence of air and water pollution and soil contamination. This is due to sources located directly on the territory and also due to 
emissions transported from external sources. The most intensive sources include those located at the industrial centres of Fil'akovo, Šahy, Lučenec and Vel'ký Krtíš,

- localization of mines in the protected area,

- location of waste dumps on the protected territories.

B. Problems of endangering natural resources - these are produced due to the influence of stress factors on particular natural resources. This territory has the following problems:

a activation of landslides at Ĺuboriečka and Baňa Dolina localities as a result of brown coal exploitation,

a possibility of endangering water resources by ineffective sediment elimination from the sewage water plant, and also sewage water permeating from septic tanks and cesspools,

$\square$ endangered water resources from animal husbandry, with localization of livestock farms in the proximity of these resources,

- affected hydrological regime in the Baňa Dolina area as result of mineral exploitation,

- influences on water resource quality from soil contamination in protected underground water resource zones at Kalonda, Dolné Plachtince, Ĺuboreč and Čebovce-Opatová,

endangered mineral waters in the Slatina locality, from polluted underground water,

clash of intensive agricultural utilisation in the water-resource protected zones with their protected function,

a damage to forests resulting from mineral mining,

$\square$ endangerment of soil resources as a consequence of industries located close to the industrial centres of Šahy, Lučenc, Vel'ký Krtíš, Fil'akovo, Vel'ké Zlievce, Vrbovka and Vinica. These areas suffer from vast emission sources,

a endangement of soil resources due to transport exhalations along the most intensively loaded transport corridors: 1/75 (north border of the study area), 510008 (Vyškovce nad Ipl'om - Šahy), I/66, I/71 (border of the study area - Fil'akovo, Biskupice - Radzovce), II/527 (Vel'ký Krtíš - Slovenské Ďarmoty), II/564 (Kamenica nad Hronom - Štúrovo), II/585 (Lučenec - Vel'ká nad Ipl'om),

soil contamination by the following heavy metals: $\mathrm{Cu}$ - in the lowlands of the region as a result of past intensive agriculture; $\mathrm{Pb}$ - in the river floodplains of the Ipel' and Štiavnica; $\mathrm{Hg}$ in the river Hron floodplain; $\mathrm{Cd}$ - in the river floodplains of the Ipel', Štiavnica and Hron; and As - in the southern part of the study area,

$\square$ affected landscape structure by creation of anthropogenic relief, including the open and aboveground mines, and also stone pits,

- clash of mining activities with agricultural and water management activities, involving changes in the hydrological regime and the acceleration of erosional processes and soil occupation,

$\square$ endangered soil resources by erosion often resulting from incorrect management of the agricultural landscape. The most endangered localities are: Želovce - Čeláre, Dolné Plachtince - Slovenské Ďarmoty, Šahy - Pláštovce, Lučenec and Vel'ký Krtíš,

- endangered water resources, due to release of waste water from industrialization and urbanisation; as in Lučenec, Vel'ký Krtíš, Fil'akovo, Lute, a. s. Lučenec and Bana Dolina. 
C. Problems of endangering individuals and their environment - these are produced by stress on individuals and on their environment. The following problems are important in this category:

$\square$ danger to the settlement area from air pollution, soil contamination and water pollution. The most at risk are settlements situated on the study area borders, at Šahy, Fil'akovo, Vel'ký Krtíšs, Balog nad Ipl'om, Vel'ké Zlievce and Vinica, Vrbovka,

a danger to human health from consuming polluted water,

danger to the environment due to increased noise from transport development. The most endangered populations reside in the following settlements: Horné a Dolné Semerovce, Šahy, Demandice, Čebovce, Pribelce, Dolné Plachtince, Pôtor, Slovenské Klačany, Závody, Fil'akovské Kováčovce, Biskupice, Radzava, Malý Krtíš, Nová Ves, Sklabina, Želovce, Záhorce, Slovenské Ďarmoty, Kremnica nad Hronom, Vel'ká nad Ipl'om, Panicke Dravce, Výškovce nad Ipl'om, Vel'ká nad Ipl'om and Presel'any nad Ipl'om,

negative influences of animal production in settlement areas. This involves co-existent hygienic zones for both animals and humans, in the habitation areas,

- danger to settlements from radon risk: These areas include Dúbrava - Závada, Vysoká nad Ipl'om - Ipel'ské Ul'any - Hrušov - Čelovce, Koláre - Želovce and Bušince (Čížek et al., 1992),

u unfavourable hygienic and aesthetic influence of technical objects in the landscape.

\section{Proposal for sustainable utilisation of the territory}

The basic output of the evaluation is the proposal for elimination of the identified problems. Proposals can be divided into the following basic categories:

A. Proposal for improvement in socio-economic conditions and the overall quality of life. This primarily entails ensuring the following requisites; the basic existential requirements of housing, the provision of food and water and also work opportunities; and also the personaldevelopmental needs of education, culture, recreation, health treatment and religious and political freedom of the population. In order to achieve this, it is important to take the following measures:

- To strengthen the economic basis of the region. To maintain and improve agriculture, and support alternative farming, such as healing plants and berries; to increase small industrial production based on the region's potential. This involves local artisanship, including individualization of agricultural products and traditional handicraft production of artistic smithery, wood crafts and needlework; to ensure support for agro tourism in compliance with nature protection and protection of natural resources,

- To create sufficient work opportunities for local inhabitants, and minimize the impact of depopulation and settlement deterioration, to effectively use the region's human resources, and their qualification and abilities, and to reinforce local traditions, to create motivational conditions to keep younger people in the region, and thus improve its demographic structure. These measures need support from the Government of the Slovak republic in cooperation with the regional and local government, in the form of grant support schemes, support for local entrepreneurs, attracting foreign investors, etc, 
since this is a marginal region. Marginal regions without the help from the outside are not able to solve these problems,

- To ensure an ecologically supportable transportation network in the region, and to improve the quality of main transport corridors, transport lines and travel efficiency,

- To support the self-supply, self-help and autonomy of the region,

- To support cooperation among the villages, appropriate is the creation of associations of municipalities, especially smaller ones which do not have changes to successfully participate in the various grant schemes. A number of grant schemes are intended only for certain size categories of municipalities,

- To enhance environmental, law awareness and civic consciousness. To ensure the highest possible involvement of inhabitants in decision making and in public affairs administration. The implementation of these measures necessarily require a continual education of the population and quality dissemination and promotion activities It is a difficult and time-consuming process,

- To apply preventive measures against public danger, criminality, and also negative psycho-social phenomena,

- To support local traditions and to preserve the "spirit" and local uniqueness of the region, encouraging the diversity of material and non-material cultural expression, to promote activities to preserve the region's cultural-historical values, to increase the inhabitants' cultural-historical awareness, thus aiding the positive identification of the inhabitants towards the cultural-historical values of the area,

- To support traditional handicrafts, and also the relationship of the native people to the region, thus enhancing affection and sense of belonging to the community. To encourage the revival and enjoyment of collective activities such as sporting events.

B. Proposal on the improvement environmental conditions - this is a set of measures which can be divided into the following main groups:

- Proposal of the creation of new landscape structure - aimed at the change of the land use on the localities where the present utilisation of the territory is not in harmony with natural potential - proposal of the green infrastructure creation of the functional ecological network mainly in the agricultural part of landscape, creation of the buffer zone along water flows, aforestation, application measures against occurrence of erosion process - establishment of the permanent grassland on the localities endangered by erosion, apply the after contour plowing selection of appropriate crops, ecological and organic farming on agricultural land, planting the protected vegetation around permanent and mobile resources of emission (animal farms, industrial areas, intensive transport lines, etc.), removal and recultivation of the waste dumps etc.,

- Proposal of technological measures - proposal of the technological measures concentrated at the elimination of the influence of stress factors: prefer environmentally friendly technologies, introduce separate collection of waste in rural settlements, complete the construction of technical infrastructure - water piping, sewer system, building a sewage treatment plant, gas lines, etc.,

- Proposal of the revitalisation - revitalisation of the water flows, which represent hydric biocorridors, revitalisation of the territory damaged by exploitation of mineral, remove 
and recultivation of the waste dumps, revitalisation of the abandoned vineyards and agricultural plots, stabilisation of the sensitive areas from aspect of landslides, etc.,

- Proposal of the protection of landscape - proposal of the legislative protection of the ecologically important landscape elements (biocenters, biocorridors interactive elements, etc) and development of supporting activities aimed at the landscape protection: select the Natura 2000 sites, taking necessary measures that result from international conventions, provide sufficient education, training and promotion in the field of nature protection, ensure a system providing information about the area,

- Proposal of the monitoring - establishment of the complex monitoring aimed at the permanent control of the quality of the individual elements of the environment - air pollution control, emission control, water quality monitoring, soil contamination control, observation of the state of biota in the study area, assurance of food security, land use changes etc.

All these aspects of the care for the environment influence each other. The protection within one aspect works also for the protection of the others. Many measures should be taken on the national level, they are for example: legislative measures, measures in the area of educationinstructional process and economic measures. From this aspect, it is important to take following steps:

strengthen the strategic importance of the cross-border region;

$\square$ provide proper economic measures to strengthen the socio-economic development of the region: tax relief, state financial support, creation and support of regional funds etc.;

take education-instructional process enhancement measures.

\section{Conclusion}

Integrated landscape management is a new-age but very much actual problem setting out from the needs of landscape research as integration of natural, cultural-historical and socioeconomical resources in the given area. It follows from the necessity to solve not only the environmental problems but existentional ones of mankind arising due to the prevailing resortism in land use and protection. Its application in practice contributes not only to elimination of environmental problems, but also to the intensification of socio-economical development of the given areas in harmony with capacity abilities of natural resources. Of the area. the successful application of integrated landscape management requires many social measures on the level of legislation, economical means as well as education and teaching.

\section{Acknowledgements}

The paper is result of the solution GP 2/0120/12: Evaluation of the quality of the environment in rural areas. 


\section{References}

Antrop M. 2003. Continuity and change in landscape. In Mander Ü., Antrop M. (eds.), Multifunctional landscapes. Vol. III - Continuity and change. WIT Press, Southampton, p. 114.

Baláž P., Cicmanová S., Fendek M., Tréger M. 2000. Mineral raw materials. Yearbook. Spišská Nová Ves. The national geological Institute D. Štúra. 259 pp.

Bezák P. 2006. Integrated approach to the evaluation landscape on the example of research in National Park Poloniny. In: IZAKOVIČOVÁ Z., (ed.): Integrated landscape management - basic tool of the implementation of the sustainable development. ILE SAS, Ministry of Environment. Bratislava, p. $125-130$.

Bodiš D., Rapant S. 1999. The geochemical atlas-River sediments. Ministry of Environment SR GS SR, Bratislava, 145 pp.

Bürgi M., Hersperger A. H., Schneeberger N. 2004. Driving forces of landscape change - current and new directions. Landscape Ecol. 19, p. 857-868.

Cairns Jr. J., Crawford T. V., Salwasser H. (eds). 1994. Implementing Integrated Environmental Management. Virginia Polytechnic Institute and State University, Blacksburg, VA. In.: Sclocombe D.S. 1998: Lessons from experience with ecosystem-based management. Landscape and Urban Planning 40, p. 31-39.

Hietel E., Waldhardt R., Otte A. 2004. Analysing land-cover changes in relation to environmental variables in Hesse, Germany. Landscape Ecol. 19, p. 473-489.

Hraško J. et al.1993. Soil map of SRM: 400 000, Research Institute of soil fertility Bratislava.

Iverson L. R. 1988. Land-use changes in Illinois, USA: The influence of landscape attributes on current and historic land use. Landscape Ecol. 2, p. 45-61.

Izakovičová Z. et al. 2000. Territorial system of ecological stability. Landscape 21. Ministry of Environment Bratislava, 232 pp. (in Slovak).

Izakovičová Z., Miklós L., Drdoš J. 1997. Landscape-ecological conditions of the sustainable development. Veda Bratislava. pp. 183. (in Slovak).

Krahulec P. a kol. 1978. Mineral water of Slovakia. Krenografia, Martin, pp. 1034.

Lehotský M. 2006. Water landscape and their sustainable development - new area for application of the integrated approach. In: Izakovičová Z., (eds). Integrated landscape management - basic tool of the implementation of the sustainable development. ILE SAS, Ministry of Environment. Bratislava, 155 - 159 pp.

Lörinci R., Balázs K. 2003. Historical land use analysis and landscape development investigations for devising sustainable land use structure: Case from Hungary. In Mander Ü., Antrop M. (eds.), Multifunctional landscapes. Vol. III - Continuity and change. WIT Press, Southampton, p. 243-262.

Miklós L., Izakovičová Z. 1997. Landscape as geosystem. Veda Bratislava, 152 pp.

Miklós L., Izakovičová Z. et al. 2003. Landscape-ecological evaluation Ipel river basin. Institute of Landscape Ecology, SAS, 183 pp. (in Slovak). 
Miklós L., Izakovičová Z. et al. 2011, Geographic information system of Ipel' basin. Institute of Landscape Ecology SAS, UNESCO Chair, Faculty of Ecology and Environmental fields, Technical University in Zvolen, Esprit Banská Štiavnica, 143 pp.

Mitchley J., Tzanopoulos J., Cooper T. 2005. Reconciling conservation of biodersity with declining agricultural use in the mountains of Europe. In: Taylor L., Ryall A. (eds.): Interdisciplinary research and management in mountain areas. The Banff Centre Canada, p. 61-65.

Ružičková H., Halada L'., Jedlička J., Kalivodová E. (eds). 1996. Biotopes of Slovakia. Institute of Landscape Ecology, SAS, 192 pp.

Sclocombe D.S. 1998. Lessons from experience with ecosystem-based management. Landscape and Urban Planning 40, p. 31-39.

Siebert R. et al. 2004. Mobilizing the European social research potential in support of biodiversity and ecosystem management. International Report - Sobio, $90 \mathrm{pp}$.

Slobodník V., Kadlečík J. (eds). 2000. Wetlands of the Slovak Republic. SZOPK, Prievidza, 148 pp.

Szaro C. R., Sexton W. T., Malone Ch.R. 1998. The emergence of ecosystem management as a tool for meeting people's needs and sustaining ecosystems. Landscape and Urban Planning, 40, p. 1-7.

Wiggering D., Glemnitz H., Muller S., Stachow Z. 2007. Indicators for multifunctionality impacts in landscape. In: Bunce J., Hojas W. 25 Years of Landscape Ecology: Scientific principles in practice. Proceeding from the 7th IALE World Congress - 2. part. p. 817-818.

World Commission on Environment and Development (WCED). Our common future. Oxford: Oxford University Press, 1987. p. 43. 